\title{
Analisis Efektivitas Biaya Kombinasi Obat Antihipertensi Pada Pasien Rawat Inap Di RS PKU Muhammadiyah Yogyakarta Tahun 2020
}

\section{Cost-Effectiveness Analysis Of Antihipertensive Combination On Hospitalization Patients At Pku Muhammadiyah Yogyakarta In 2020}

\author{
Assysifa Septyani Putri ${ }^{(1)}$, Niken Dyahariesti ${ }^{(2)}$ \\ (1)(2) Prodi Farmasi , Fakultas Kesehatan, Universitas Ngudi Waluyo \\ Email: assysifaputri55@gmail.com
}

\begin{abstract}
ABSTRAK
Terapi kombinasi disarankan pada pasien hipertensi yang memiliki tekanan darah tidak terkontrol dengan terapi tunggal. Biaya pengobatan semakin meningkat setiap tahunnya. Penelitian ini bertujuan untuk mengetahui terapi kombinasi obat antihipertensi yang paling cost effective pada pasien rawat inap RS PKU Muhammadiyah Yogyakarta tahun 2020. Penelitian ini merupakan penelitian deskriptif dengan pendekatan analisis farmakoekonomi metode Cost Effectiveness Analysis (CEA) yang dilakukan secara retrospektif. Teknik pengambilan sampel yang digunakan adalah total sampling. Data dikelompokkan berdasarkan pola terapi pasien kemudian dilakukan analisis berdasarkan ACER dan ICER. Jenis pola terapi kombinasi antihipertensi yang paling banyak digunakan adalah kombinasi dua obat (53\%). Terapi dengan ACER terendah yaitu Diuretik $^{\mathrm{a}}+\mathrm{ARB}+\beta$ Bloker (Rp. 15.257). Hasil ICER kombinasi ACEI + CCB $+\beta$ Bloker + Diuretik $^{b}+$ Agonis $\alpha 2$ Sentral + ACEI memiliki nilai yang terendah dengan Rp. 25.353 jika dibandingkan dengan terapi standar. Namun, terapi CCB $+\beta$ Bloker, Diuretik ${ }^{\mathrm{a}}+\mathrm{ACEI}+\mathrm{CCB}$, Diuretik $^{\mathrm{a}}+\mathrm{ARB}+\beta$ Bloker, ARB $+\mathrm{CCB}+\beta$ Bloker + Agonis $\alpha 2$ Sentral bersifat dominan terhadap terapi standar pada cost effectiveness grid. Sehingga, terapi yang paling cost effective berdasarkan ACER dan ICER adalah Diuretik ${ }^{\mathrm{a}}+\mathrm{ARB}+\beta$ Bloker.
\end{abstract}

Kata kunci: Antihipertensi, efektivitas, biaya.

\section{ABSTRACT}

Combination therapy is recommended in hypertensive patients whose blood pressure is not controlled by monotherapy. Medical expenses are increasing every year. This study aims to determine the most cost-effective antihypertensive drug combination therapy for inpatients at PKU Muhammadiyah Yogyakarta Hospital in 2020. This study is a descriptive study with a pharmacoeconomic analysis approach using the Cost-Effectiveness Analysis (CEA) method which was carried out retrospectively. The sampling technique used is total sampling. The data were grouped based on the patient's therapy pattern and then analyzed based on ACER and ICER. The most widely used combination antihypertensive therapy pattern was a combination of two drugs (53\%). The therapy with the lowest ACER was Diuretic ${ }^{\mathrm{a}}+\mathrm{ARB}+\quad$ Blockers (Rp. 15.257). The ICER result of the combination of ACEI + CCB + Blocker + Diuretic ${ }^{b}+$ Central $\alpha 2$ Agonist + ACEI has the lowest value with Rp. 25,353 when compared to standard therapy. However, $\mathrm{CCB}+$ Blocker, Diuretic ${ }^{\mathrm{a}}+\mathrm{ACEI}+\mathrm{CCB}$, Diuretic $+\mathrm{ARB}+$ Blocker, ARB +

$\mathrm{CCB}+$ Blocker + Central $\alpha 2$ Agonist are dominant over standard therapy on the costeffectiveness grid. Thus, the most cost-effective therapy based on ACER and ICER is Diuretic ${ }^{\mathrm{a}}+$ ARB $+\quad$ Blockers..

Keywords: Antihypertensive, effectiveness, cost. 


\section{PENDAHULUAN}

Hipertensi merupakan salah satu faktor risiko utama penyakit kardiovaskular yang hingga saat ini masih menjadi tantangan kesehatan masyarakat. Berdasarkan data WHO (2014) hipertensi telah menyebabkan sekitar 9,4 juta kematian di dunia. American Health Association (2020) melaporkan bahwa pada tahun 2013 hingga 2016 sekitar 46\% atau 116,4 juta orang dewasa di Amerika yang berusia $\geq 20$ tahun mengalami hipertensi. Pravalensi penyakit ini pada tahun 2025 u diperkirakan akan mengalami peningkatan menjadi 1,56 milyar kasus (Tabrizi, Bazargani, Farahbaksh, L.Nikniaz, \& Z.Nikniaz, 2016).

Indonesia juga memiliki angka pravelensi hipertensi yang cukup tinggi pada penduduk $\geq$ 18 tahun, berdasarkan pengukuran secara nasional yaitu sebesar 34,11\% dan Daerah Istimewa Yogyakarta menempati urutan ke-12 dengan 32,86\% (Kemenkes R.I.,2019). Berdasarkan laporan surveilans terpadu penyakit (STP) di Daerah Istimewa Yogyakarta tahun 2019 hipertensi menempati urutan pertama dalam 10 penyakit terbesar di rawat inap rumah sakit dengan total 15.388 kasus (Dinkes D.I Yogyakarta,2019).

Terapi farmakologi hipertensi diberikan ketika tekanan darah sistolik pasien $\geq 150$ $\mathrm{mmHg}$ atau tekanan darah diastolic $\geq 90 \mathrm{mmHg}$. Pemberian terapi itu bertujuan agar pasien dapat mencapai dan mempertahankan target tekanan darah. Jika target tekanan darah tidak tercapai dalam 1 bulan perawatan maka akan dilakukan peningkatan dosis atau pemberian terapi kombinasi (Muhadi,2016).

Terapi kombinasi memiliki tingkat efektifitas yang lebih baik dalam menurunkan tekanan darah pasien, tetapi dapat meningkatkan total biaya pengobatan. Hal tersebut akan menjadi beban ekonomi pasien hipertensi khususnya bagi masyarakat yang memiliki ekonomi menengah kebawah karena penatalaksanaan terapi dilakukan dalam jangka panjang atau bahkan seumur hidup, sedangkan biaya pengobatan semakin meningkat setiap tahunnya (Udayani, Riastini, \& Putra, 2018; Zulfah, Ikaditya, \& Kosasih, 2019).

Keterbatasan sumber daya khususnya tenaga ahli, waktu, fasilitas dan alat kesehatan dalam menjalankan sistem pelayanan mengakibatkan kebutuhan dana yang terus meningkat di setiap institusi pelayanan kesehatan. Prioritas terhadap teknologi kesehatan perlu dilakukan untuk mengatasi keterbatasan tersebut terutama untuk pemilihan obat. Sehingga sumber daya yang tersedia dapat digunakan secara efisien berdasarkan skala prioritas yang telah dibuat dengan objektif (Putri,2018).

Faktor efikasi merupakan salah satu pertimbangan yang penting dalam pemilihan obat dalam menurunkan tekanan darah dan mengurangi kardiovaskular (CVD) termasuk stoke, infark miokard, dan gagal jantung agar tercapai peningkatan kesehatan yang maksimal di tengah keterbatasan yang ada (Rahayu, Afdhal, Hasan, Suwarna, \& Meila, 2020). Sehingga perlu dilakukannya penelitian mengenai efektivitas biaya dan terapi kombinasi obat antihipertensi pada pasien rawat inap di RS PKU Muhmaadiyah Yogyakarta secara retrospektif dengan metode cost effectiveness analysis agar dapat mengetahui pilihan obat yang paling efektif secara biaya dan terapi.

\section{METODE PENELITIAN}

\section{Alat dan Bahan}

Alat dan bahan yang digunakan dalam penelitian ini yaitu lembar pengumpulan data yang dibuat oleh peneliti, rekam medis dan rincian pembayaran pasien hipertesi rawat inap RS PKU Muhammadiyah Yogyakarta tahun 2020.

\section{Metode Penelitian}

Penelitian ini termasuk dalam penelitian deskriptif dengan pendekatan analisis farmakoekonomi menggunakan metode Cost Effectiveness Analysis (CEA) yang ditinjau berdasarkan perspektif rumah sakit. Pengambilan data dilakukan secara retrospektif 
dengan cara total sampling berdasarkan kriteria inklusi dan eksklusi menggunakan data pasien hipertensi rawat inap RS PKU Muhammadiyah periode Januari hingga Desember 2020. Adapun kriteria inklusi pada penelitian ini yaitu pasien hipertensi yang menjalani rawat inap tahun 2020 dengan usia $>18$ tahun dan memiliki diagnosis utama hipertensi primer tanpa atau dengan penyakit penyerta, pasien dengan terapi kombinasi obat antihipertensi yang sama selama masa perawatannya, pasien dengan data rekam medis dan rincian biaya yang lengkap.

Sedangkan kritera eksklusi yang digunakan yaitu pasien hipertensi yang mengakhiri masa perawatan atau pulang paksa, pasien hipertensi pada masa kehamilan dan pasien yang meninggal dunia saat masa perawatan. Terapi yang cost effective dapat diketahui melalui:

a. Analisis biaya yang dilakukan dengan menghitung total biaya dari rata-rata tiap komponen biaya medik langsung pasien.

b. Analisis efektivitas terapi dilakukan melalui perhitungan persentase efektivitas terapi berdasarkan rumus dibawah ini:

$\%$ Efektivitas $=\frac{a}{b} \times 100 \%$.

Keterangan:

a: jumlah pasien yang mencapai target tekanan darah

b: jumlah pasien

c. Analisis efektivitas biaya dilakukan melalui perhitungan ACER dan ICER dengan menggunakan rumus dibawah ini:

$A C E R=\frac{\text { Biaya Perawatan }(\mathrm{Rp})}{\text { Efektivitas }(\mathrm{g} 6)} \ldots$.
ICER $=\frac{\Delta \text { biaya }}{\Delta \text { efek }} \ldots \ldots \ldots \ldots \ldots \ldots \ldots \ldots \ldots$

Keterangan:

$\Delta$ biaya: biaya teknologi baru dikurangi biaya pembanding

$\Delta$ efek: efek teknologi baru dikurangi biaya pembanding

\section{HASIL DAN PEMBAHASAN}

Hasil

Tabel 1. Gambaran Karakteristik Pasien

\begin{tabular}{|c|c|c|}
\hline Karakteristik Pasien & Jumlah & Persentase \\
\hline \multicolumn{3}{|l|}{ Usia } \\
\hline 26-35 Tahun & 2 & $10,53 \%$ \\
\hline 36-45 Tahun & 1 & $5,26 \%$ \\
\hline 46-55 Tahun & 9 & $47,37 \%$ \\
\hline 56-65 Tahun & 2 & $11,53 \%$ \\
\hline$>65$ Tahun & 5 & $26,32 \%$ \\
\hline Jumlah & 19 & $100 \%$ \\
\hline \multicolumn{3}{|l|}{ Jenis Kelamin } \\
\hline Perempuan & 4 & $21,05 \%$ \\
\hline Laki-laki & 15 & $78,95 \%$ \\
\hline Jumlah & 19 & $100 \%$ \\
\hline \multicolumn{3}{|l|}{ Diagnosis HT } \\
\hline Tanpa penyerta & 4 & $21,05 \%$ \\
\hline Dengan Penyerta & 15 & $78,95 \%$ \\
\hline Jumlah & 19 & $100 \%$ \\
\hline \multicolumn{3}{|l|}{ Klasifikasi HT } \\
\hline HT Stage II & 3 & $15,79 \%$ \\
\hline HT Emergensi & 2 & $10,53 \%$ \\
\hline HT Urgensi & 14 & $73,68 \%$ \\
\hline Jumlah & 19 & $100 \%$ \\
\hline \multicolumn{3}{|l|}{ Penyakit Penyerta } \\
\hline AFRVR & 1 & $6,67 \%$ \\
\hline Bacterial Infection + Vertigo & 1 & $6,67 \%$ \\
\hline Cephalgia Akut & 1 & $6,67 \%$ \\
\hline Dyspepsia & 1 & $6,67 \%$ \\
\hline Dyspepsia + Dizzyness & 1 & $6,67 \%$ \\
\hline DM Tipe $2+$ Dislipidemia & 1 & $6,67 \%$ \\
\hline DM Tipe $2+$ Hiperglikemia & 1 & $6,67 \%$ \\
\hline $\begin{array}{l}\text { DM Tipe } 2+\text { Hiperglikemia }+ \\
\text { Pasca Stroke }\end{array}$ & 1 & $6,67 \%$ \\
\hline Epitaksis Posterior & 1 & $6,67 \%$ \\
\hline Epitaksis Anterior & 1 & $6,67 \%$ \\
\hline Headache & 1 & $6,67 \%$ \\
\hline HHD + Vertigo & 1 & $6,67 \%$ \\
\hline HHD + UTI & 1 & $6,67 \%$ \\
\hline Gout + Dislipidemia & 1 & $6,67 \%$ \\
\hline Vertigo & 1 & $6,67 \%$ \\
\hline Jumlah & 19 & $100 \%$ \\
\hline \multicolumn{3}{|l|}{ Kelas Perawatan } \\
\hline Utama & 5 & $26,32 \%$ \\
\hline Kelas I & 2 & $10,53 \%$ \\
\hline Kelas II & 4 & $21,05 \%$ \\
\hline Kelas IIIA & 8 & $42,11 \%$ \\
\hline Jumlah & 19 & $100 \%$ \\
\hline \multicolumn{3}{|c|}{$\begin{array}{l}\text { Ket: } \mathrm{HT}=\text { Hipertensi; AFRVR }=\text { Artrial Fibrilation } \\
\text { with Rapid Ventricular Response; DM = Diabetes } \\
\text { Melitus; HHD = Hipertensive Heart Disease; UTI = } \\
\text { Urinary Tract Infection }\end{array}$} \\
\hline
\end{tabular}


Gambaran karakteristik pasien hipertensi dikelompokkan berdasarkan usia, jenis kelamin, diagnosis HT, klasifikasi HT, penyakit penyerta dan ruang perawatan yang disajikan pada Tabel (1). Penggunaan terapi kombinasi antihipertensi pada pasien hipertensi rawat inap di RS PKU Muhammadiyah Yogyakarta terdiri dari kombinasi dua obat sebanyak 10 pasien (53\%), kombinasi tiga obat sebanyak 5 pasien $(26 \%)$, kombinasi empat obat sebanyak 3 pasien (16\%) dan kombinasi enam obat antihipertensi sebanyak 1 pasien (5\%) yang disajikan pada Gambar (1).

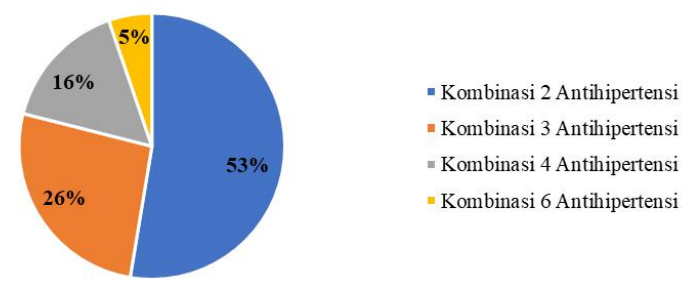

Gambar 1. Gambaran Penggunaan Obat Kombinasi

Berdasarkan hasil studi diketahui bahwa pola terapi yang paling banyak digunakan oleh pasien rawat inap merupakan kombinasi obat golongan CCB dengan antihipertensi lainnya yang dapat dilihat pada Tabel (2). Richards dan Tobe (2014) menjelaskan bahwa jenis obat CCB yang paling sering diresepkan adalah Amlodipin. Obat ini bekerja dengan mengurangi resistensi pembuluh darah perifer dengan menghalangi pergerakan transmembran kalsium dan mengurangi tonus otot polos pembuluh darah. Kombinasi dua obat antihipertensi golongan $\mathrm{CCB}$ dan $\mathrm{ARB}$ merupakan pilihan terapi yang paling banyak digunakan dengan total 5 pasien $(26,32 \%)$.

Terdapat enam golongan obat yang digunakan untuk tatalaksana terapi yaitu ACEI, Agonis $\alpha 2$ sentral, ARB, $\beta$ Bloker, $\mathrm{CCB}$ dan Diuretik yang disajikan pada Gambar 4.3. Hal tersebut sesuai dengan JNC 8 yang merekomendasikan CCB, ARB, ACEI atau Diuretik sebagai terapi utama pada pasien dan menurut Nafrialdi (2007) $\quad \beta$ Bloker juga termasuk dalam golongan obat yang lazim digunakan sebagai terapi awal hipertensi. Pada golongan CCB obat yang paling banyak digunakan adalah Amlodipin, pada golongan ARB yaitu Candesartan, pada golongan ACEI yaitu Captopril, pada golongan Diuretik yaitu Furosemid, sedangkan pada golongan $\beta$ Bloker yaitu Bisoprolol.

Tabel 2. Gambaran Pola Terapi Kombinasi

\begin{tabular}{|c|c|c|}
\hline Jenis Kombinasi & Jumlah & Persentase \\
\hline \multicolumn{3}{|l|}{ Kombinasi 2 Antihipertensi } \\
\hline $\mathrm{ACEI}+\mathrm{CCB}$ & 1 & $5,26 \%$ \\
\hline $\mathrm{CCB}+\mathrm{ARB}$ & 5 & $26,32 \%$ \\
\hline $\mathrm{CCB}+\beta$ Bloker & 2 & $10,53 \%$ \\
\hline $\mathrm{ARB}+\beta$ Bloker & 1 & $5,26 \%$ \\
\hline $\mathrm{ACEI}+\mathrm{ARB}$ & 1 & $5,26 \%$ \\
\hline \multicolumn{3}{|l|}{ Kombinasi 3 Antihipertensi } \\
\hline $\mathrm{CCB}+\mathrm{ARB}+$ Diuretik $^{\mathrm{b}}$ & 1 & $5,26 \%$ \\
\hline Diuretik $^{\mathrm{a}}+\mathrm{ACEI}+\mathrm{CCB}$ & 1 & $5,26 \%$ \\
\hline Diuretik $^{\mathrm{a}}+\mathrm{ARB}+\beta$ Bloker & 2 & $10,53 \%$ \\
\hline $\mathrm{ACEI}+\mathrm{CCB}+\beta$ Bloker & 1 & $5,26 \%$ \\
\hline \multicolumn{3}{|l|}{ Kombinasi 4 Antihipertensi } \\
\hline $\begin{array}{l}\text { ACEI }+ \text { CCB }+\beta \text { Bloker }+ \\
\text { Diuretik }^{b}\end{array}$ & 1 & $5,26 \%$ \\
\hline $\begin{array}{l}\text { Diuretik }^{\mathrm{a}}+\mathrm{ARB}+\mathrm{CCB}+\beta \\
\text { Bloker }\end{array}$ & 1 & $5,26 \%$ \\
\hline $\begin{array}{l}\mathrm{ARB}+\mathrm{CCB}+\beta \text { Bloker }+ \\
\text { Agonis } \alpha 2 \text { Sentral }\end{array}$ & 1 & $5,26 \%$ \\
\hline Kombinasi 6 Antihipertensi & & \\
\hline $\begin{array}{l}\mathrm{ACEI}^{\mathrm{a}}+\mathrm{CCB}+\beta \text { Bloker }+ \\
\text { Diuretik }+ \text { Agonis } \alpha 2 \text { Sentral } \\
+\mathrm{ACEI}^{\mathrm{b}}\end{array}$ & 1 & $5,26 \%$ \\
\hline Total & 19 & $100 \%$ \\
\hline
\end{tabular}

Ket: ACEI $^{\mathrm{a}}=$ Captopril; ACEI $^{\mathrm{b}}=$ Lisinopril; $_{\text {Diuretik }}{ }^{\mathrm{a}}=$ Furosemid; Diuretik ${ }^{\mathrm{b}}=\mathrm{HCT}$

Tujuan dari perhitungan ACER yaitu untuk membandingkan total biaya suatu terapi atau alternatif pengobatan dengan outcome klinis untuk menghasilkan perbandingan yang mewakili biaya pada tiap hasil klinis yang spesifik dan independent dari pembanding (Wahyuningtyas et al., 2015). Suatu terapi dapat dikatakan efektif secara biaya dan terapi apabila memiliki nilai ACER yang paling rendah diantara pilihan alternatif lainnya. Berdasarkan Tabel (3) diketahui bahwa pada terapi kombinasi $\mathrm{ACEI}+\beta$ Bloker, $\mathrm{ARB}+\beta$ Bloker, $\mathrm{ACEI}+\mathrm{ARB}, \mathrm{CCB}+\mathrm{ARB}+$ Diuretik $^{\mathrm{a}}$, ACEI 
$+\mathrm{CCB}+\beta$ Bloker, $\mathrm{ACEI}+\mathrm{CCB}+\beta$ Bloker + Diuretik $^{\mathrm{b}}$ dan terapi $\mathrm{ACEI}^{\mathrm{a}}+\mathrm{CCB}+\beta$ Bloker + Diuretik + Agonis $\alpha$ Sentral $+\mathrm{ACEI}^{\mathrm{b}}$ nilai ACER nol atau tidak dapat ditampilkan karena tidak ada persentase efektivitas yang diberikan pada terapi ini.

Tabel 3. Perhitungan ACER Kombinasi Antihipertensi

\begin{tabular}{|c|c|c|c|}
\hline Jenis Kombinasi & C (Rp) & E (\%) & ACER \\
\hline \multicolumn{4}{|c|}{ Kombinasi 2 Antihipertensi } \\
\hline $\mathrm{ACEI}+\mathrm{CCB}$ & 3.099 .100 & 0 & 0 \\
\hline $\mathrm{CCB}+\mathrm{ARB}$ & 4.011 .960 & 20 & 133.732 \\
\hline $\mathrm{CCB}+\beta$ Bloker & 2.687 .150 & 100 & 26.872 \\
\hline ARB $+\beta$ Bloker & 1.733 .700 & 0 & 0 \\
\hline $\mathrm{ACEI}+\mathrm{ARB}$ & 2.913 .000 & 0 & 0 \\
\hline \multicolumn{4}{|c|}{ Kombinasi 3 Antihipertensi } \\
\hline $\begin{array}{l}\mathrm{CCB}+\mathrm{ARB}+ \\
\text { Diuretik }^{\mathrm{b}}\end{array}$ & 1.820 .000 & 0 & 0 \\
\hline $\begin{array}{l}\text { Diuretik }^{\mathrm{a}}+\mathrm{ACEI} \\
+\mathrm{CCB}\end{array}$ & 1.895 .150 & 100 & 18.952 \\
\hline $\begin{array}{l}\text { Diuretik }^{\mathrm{a}}+\mathrm{ARB}+ \\
\beta \text { Bloker }\end{array}$ & 1.526 .700 & 100 & 15.267 \\
\hline $\begin{array}{l}\text { ACEI }+\mathrm{CCB}+\beta \\
\text { Bloker }\end{array}$ & 2.147 .800 & 0 & 0 \\
\hline \multicolumn{4}{|c|}{ Kombinasi 4 Antihipertensi } \\
\hline 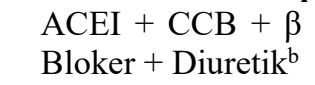 & 1.166 .300 & 0 & 0 \\
\hline $\begin{array}{l}\text { Diuretik }^{\mathrm{a}}+\mathrm{ARB} \\
+\mathrm{CCB}+\beta \text { Bloker }\end{array}$ & 6.566 .600 & 100 & 65.566 \\
\hline $\begin{array}{l}\mathrm{ARB}+\mathrm{CCB}+\beta \\
\text { Bloker }+ \text { Agonis } \\
\alpha 2 \text { Sentral }\end{array}$ & 1.969 .500 & 100 & 19.695 \\
\hline \multicolumn{4}{|c|}{ Kombinasi 6 Antihipertensi } \\
\hline $\begin{array}{l}\text { ACEI }^{\mathrm{a}}+\mathrm{CCB}+\beta \\
\text { Bloker }+ \text { Diuretik } \\
+\quad \text { Agonis } \alpha 2 \\
\text { Sentral }+ \text { ACEI }^{\mathrm{b}}\end{array}$ & 3.504 .900 & 0 & 0 \\
\hline
\end{tabular}

Ket: $\mathrm{C}=$ Rata-Rata Biaya Medik Langsung; $\mathrm{E}=$ RataRata Efektivitas; $\mathrm{ACEI}^{\mathrm{a}}=$ Captopril; $\mathrm{ACEI}^{\mathrm{b}}=$ Lisinopril; Diuretik $^{\mathrm{a}}=$ Furosemid; Diuretik ${ }^{\mathrm{b}}=$ HCT

Meskipun analisis ACER telah memberikan informasi yang bermanfaat, namun ciri khas dari analisis efektivitas biaya adalah dilakukannya analisis dengan menggunakan ICER (Andayani, 2013). Penentuan suatu terapi untuk dilakukan ICER dapat diketahui melalui cost effectiveness grid seperti yang disajikan pada Tabel (4).
Tabel 4. Cost Effectiveness Grid

\begin{tabular}{|c|c|c|c|}
\hline $\begin{array}{c}\text { Cost } \\
\text { Effectivenss }\end{array}$ & Biaya Lebih Rendah & $\begin{array}{l}\text { Biaya } \\
\text { Sama } \\
\end{array}$ & Biaya Lebih Tinggi \\
\hline $\begin{array}{l}\text { Effectivitas } \\
\text { Lebih Rendah }\end{array}$ & 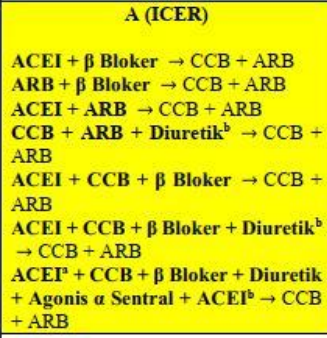 & B & $\underset{\text { (Dominated) }}{\mathrm{C}}$ \\
\hline $\begin{array}{c}\text { Efektivitas } \\
\text { Sama }\end{array}$ & D & \begin{tabular}{|c|}
$\mathbf{E}$ \\
(Arbitrary)
\end{tabular} & $\mathbf{F}$ \\
\hline $\begin{array}{l}\text { Efektivitas } \\
\text { Lebih Tinggi }\end{array}$ & \begin{tabular}{l}
\multicolumn{1}{c}{$\begin{array}{c}\text { G } \\
\text { (Dominated) }\end{array}$} \\
CCB $+\beta$ Bloker $\rightarrow$ CCB + ARB \\
Diuretik + ACEI + CCB $\rightarrow$ CCB + \\
ARB \\
Diuretik + ARB $+\beta$ Bloker $\rightarrow$ CCB \\
+ ARB \\
ARB + CCB $+\beta$ Bloker + Agonis $\alpha 2$ \\
Sentral $\rightarrow$ CCB + ARB
\end{tabular} & H & $\begin{array}{l}\quad \text { I (ICER) } \\
\text { Diuretik }+ \text { ARB + } \\
\text { CCB }+\boldsymbol{\beta} \text { Bloker } \rightarrow \\
\text { CCB }+ \text { ARB }\end{array}$ \\
\hline
\end{tabular}

Ket: ACEI $^{\mathrm{a}}=$ Captopril; ACEI $^{\mathrm{b}}=$ Lisinopril; $^{\text {Diuretik }}{ }^{\mathrm{a}}=$ Furosemid; Diuretik ${ }^{b}=$ HCT

Intrepretasi hasil:

1. Kolom A

Terapi kombinasi obat ACEI $+\beta$ Bloker, $\mathrm{ARB}+\beta$ Bloker, $\mathrm{ACEI}+\mathrm{ARB}, \mathrm{CCB}+\mathrm{ARB}+$ Diuretik $^{\mathrm{b}}$, ACEI $+\mathrm{CCB}+\beta$ Bloker, ACEI + $\mathrm{CCB}+\beta$ Bloker + Diuretik $^{\mathrm{b}}, \mathrm{ACEI}+\mathrm{CCB}+\beta$ Bloker + Diuretik $^{\mathrm{b}}+$ Agonis $\alpha 2$ Sentral memiliki efektivitas dan biaya yang lebih rendah jika dibandingkan dengan terapi kombinasi $\mathrm{CCB}+\mathrm{ARB}$, sehingga perlu dilakukan perhitungan ICER.

2. Kolom G

Terapi kombinasi obat golongan $\mathrm{CCB}+\beta$ Bloker, Diuretik ${ }^{\mathrm{a}}+\mathrm{ACEI}+\mathrm{CCB}$, Diuretik ${ }^{\mathrm{a}}+$ $\mathrm{ARB}+\beta$ Bloker, $\mathrm{ARB}+\mathrm{CCB}+\beta$ Bloker + Agonis $\alpha 2$ Sentral bersifat dominan, kerena memiliki efektivitas yang lebih tinggi dan biaya yang dikeluarkan lebih rendah jika dibandingkan denga terapi kombinasi $\mathrm{CCB}+$ ARB.

3. Kolom I

Terapi kombinasi obat Diuretik ${ }^{\mathrm{a}}+\mathrm{ARB}+$ $\mathrm{CCB}+\beta$ Bloker memiliki efektivitas dan biaya yang lebih tinggi jika dibandingkan dengan terapi kombinasi $\mathrm{CCB}+\mathrm{ARB}$, sehingga perlu dilakukan perhitungan ICER 
Tabel 5.Perhitungan ICER Kombinasi Antihipertensi

\begin{tabular}{lccc}
\hline \multicolumn{1}{c}{ Kombinasi Obat } & $\begin{array}{c}\Delta \boldsymbol{C} \\
(\mathbf{R p})\end{array}$ & $\begin{array}{c}\Delta \boldsymbol{E} \\
(\%)\end{array}$ & ICER \\
\hline ACEI + $\beta$ Bloker & -912.860 & -20 & 45.643 \\
CCB + ARB & & & \\
ARB + $\beta$ Bloker & -2.278 .260 & -20 & 113.913 \\
CCB + ARB & & & \\
ACEI + ARB & -1.098 .960 & -20 & 54.948 \\
CCB + ARB & & & \\
CCB + ARB + & & & \\
Diuretik ${ }^{\mathrm{b}}$ & -2.191 .960 & -20 & 109.598 \\
CCB + ARB & & & \\
ACEI + CCB + $\beta$ & & & \\
Bloker & -1.864 .160 & -20 & 93.208 \\
CCB + ARB & & & \\
ACEI + CCB + $\beta$ & & & \\
Bloker + Diuretik & -2.845 .660 & -20 & 142.283 \\
CCB + ARB & & & \\
Diuretik + ARB + & & & \\
CCB $\beta$ Bloker & 2.544 .640 & 80 & 31.808 \\
CCB + ARB & & & \\
ACEI + CCB + $\beta$ & & & \\
Bloker + Diuretik + & & & \\
Agonis $\alpha 2$ Sentral + & -507.060 & -20 & 25.353 \\
ACEI \\
CCB + ARB
\end{tabular}

Ket: $\Delta C=$ rata-rata biaya terapi pembanding dikurangi dengan terapi standar; $\Delta \boldsymbol{E}=$ rata-rata efektivitas terapi pembanding dikurangi dengan terapi standar; $\mathrm{ACEI}^{\mathrm{a}}=$ Captopril; $\mathrm{ACEI}^{\mathrm{b}}=$ Lisinopril; Diuretik ${ }^{\mathrm{a}}=$ Furosemid; Diuretik $^{\mathrm{b}}=$ HCT

\section{Pembahasan}

Hasil studi pendahuluan menunjukkan bahwa total kasus hipertensi di instalasi rawat inap RS PKU Muhammadiyah Yogyakarta periode Januari hingga Desember 2021 yang memenuhi kriteria inklusi dan eksklusi adalah 19 pasien. Populasi tersebut diambil berdasarkan data rekam medik yang disesuaikan dengan JNC 8 dimana diagnosis utama pasien adalah hipertensi primer. Berdasarkan data tersebut maka teknik pengambilan sampel yang digunakan pada penelitian ini yaitu total sampling. Menurut Sugiyono dan Puspandhani (2020) teknik tersebut digunakan apabila jumlah populasi relatif kecil yaitu kurang dari 30 .

Berdasarkan Tabel (1) dapat diketahui bahwa persentase kejadian kasus hipertensi terendah berada pada kelompok usia 36-45 tahun yaitu sebanyak satu pasien dengan persentase sebesar $5,26 \%$ dan mengalami peningkatan pada kelompok usia 46-55 tahun sebanyak sembilan pasien dengan persentase sebesar $47,37 \%$. Hal ini sesuai dengan penelitian Zulfah, Ikaditya dan Kosasih (2019) yang menyebutkan bahwa usia memiliki pengaruh terhadap terjadinya penyakit hipertensi, karena pertambahan usia akan meningkatkan risiko terjadinya hipertensi akibat fungsi organ yang menurun.

Hipertensi lebih banyak dijumpai pada lakilaki dibandingkan dengan perempuan. Hasil studi menunjukkan persentase pasien dengan jenis kelamin laki-laki sebanyak 15 pasien (78,95\%), sedangkan pada perempuan yaitu sebanyak 4 pasien (21,05\%). Aristoteles (2018) mengemukakan bahwa risiko terjadinya hipertensi pada laki-laki lebih besar dibandingan dengan perempuan, karena wanita biasanya terlindungi dari penyakit kardiovaskular sebelum menopause. Wanita memiliki hormon estrogen pada tubuhnya yang berperan dalam meningkatkan High Density Lipoprotein (HDL) sebagai pelindung dan mencegah terjadinya penebalan dinding pembuluh darah atau asteroklerosis. Jumlah hormon estrogen tersebut secara alami akan semakin berkurang pada usia 45-55 tahun (Aryantiningsih \& Silaen, 2018).

Jenis klasifikasi hipertensi yang paling banyak dialami oleh pasien ketika memulai masa perawatan di rumah sakit yaitu hipertensi urgensi sebanyak 14 pasien $(73,68 \%)$, kemudian hipertensi stage II sebanyak 3 pasien $(15,79 \%)$ dan hipertensi emergensi sebanyak 2 pasien (10,53\%). Menurut Devicaesaria (2014) 20\% pasien yang datang ke UGD merupakan pasien hipertensi krisis. Selain itu, menurut Breu dan Axon (2018) hipertensi krisis sering terjadi pada pasien rawat inap dengan sekitar satu dari tujuh pasien mengalami episode hipertensi emergensi atau urgensi. Hipertensi emergensi terjadi jika nilai tekanan darah $>180 / 120 \mathrm{mmHg}$ dengan adanya kerusakan organ target. Organ yang paling sering terkena yaitu otak, jantung, pembuluh darah besar dan ginjal. Sedangkan 
pada pasien dengan hipertensi urgensi terjadi peningkatan tekanan darah yang sama tetapi tidak memiliki gejala atau tanda yang menunjukkan adanya kerusakan organ.

Jumlah pasien hipertensi dengan penyakit penyerta lebih besar dengan total 15 pasien (78,95\%) dibandingan dengan pasien tanpa penyakit penyerta yaitu sebanyak 4 pasien $(21,05 \%)$. Hipertensi memiliki berbagai komplikasi, seperti peningkatan kekakuan aorta, gangguan ginjal dan kasus kejadian kardiovaskular. Kondisi ini akan terjadi jika tidak ada upaya untuk menstabilkan tekanan darah dengan pola hidup sehat dan konsumsi obat-obatan.

Adapun jenis penyakit penyerta yang ditemukan pada pasien yaitu Artrial Fibrillation with Rapid Ventricular Respon (AFRVR), bacterial infection, vertigo, dispepsia, dizziness, DM tipe 2, dislipidemia, hiperglikemia, pasca stroke, epitekasis, headache, Hypertensive Heart Disease (HHD), Urinary Tract Infection (UTI), dan gout. Menurut Wang, Monticone dan Lakatta (2016) lebih dari 70\% orang dewasa yang lebih tua dengan insiden infark miokard, stroke, sindrom aorta akut, dan gagal jantung memiliki hipertensi yang sudah ada sebelumnya.

Berdasarkan ruang perawatan pasien hipertensi banyak yang menjalani perawatan pada kelas IIIA yaitu sebanyak 8 pasien (42,11\%). Ruang kelas IIIA terdiri dari ruang Marwah dan Raudah. Kemudian kelas Utama dengan total 5 pasien $(26,32 \%)$, yang terdiri dari ruang Zam-zam dan Shafa. Kelas II yang terdiri dari ruang Raudah dan Shafa dengan jumlah pasien hipertensi sebanyak 4 pasien $(21,05 \%)$. Sedangkan pada ruang kelas I terdapat 2 pasien $(10,53 \%)$ yang berada pada ruang Shafa.

Terapi kombinasi umumnya digunakan pada hipertensi stage II atau pasien hipertensi dengan penyakit penyerta. Terapi kombinasi dengan dosis yang lebih rendah lebih baik digunakan daripada terapi tunggal dengan dosis tinggi, hal ini karena dosis yang rendah memiliki efek samping yang lebih rendah (Saseen \&
Maclaughlin, 2011). Berdasarkan Gambar (1) dapat diketahui bahwa kombinasi dua obat antihipensi menjadi pilihan terapi yang paling banyak digunakan dengan total 10 pasien $(53 \%)$. Keadaan tersebut sesuai dengan algoritma terapi hipertensi pada JNC 8 yang menyarankan bahwa pemilihan jenis kombinasi obat perlu mempertimbangkan kondisi pasien.

Menurut James (2014) tekanan darah yang tidak dapat mencapai target dengan dua obat, maka dapat diberikan titrasi obat dari golongan yang direkomendasikan. Jika tiga obat pun belum mampu mencapai target tekanan darah dan pasien membutuhkan lebih dari tiga obat, maka antihipertensi golongan lain dapat diberikan. Kombinasi CCB dengan ARB lebih banyak diberikan pada pasien hipertensi karena bisa ditoleransi dengan baik pada awal pengobatan dan lebih unggul dari kombinasi dengan diuretik dalam menghambat stimulasi RAAS, serta dapat mengurangi stress oksidatif, rigiditas arteri, menurunkan risiko progresifitas stroke dan penuaan vaskular (Putri, Satriyasa, \& Jawi, 2019).

$\beta$ Bloker adalah salah satu obat yang paling sering digunakan pada pasien dengan fibrilasi atrium dan untuk mencegah kejadian pertama atau kekambuhan fibrilasi atrium, terutama pada pasien dengan hipertensi. Selain itu $\beta$ Bloker telah digunakan dalam kombinasi dengan CCB untuk mengurangi takikardia dan untuk menghasilkan penurunan tekanan darah yang lebih besar (Dorian \& Angaran, 2014; Richards \& Tobe, 2014).

Antihipertensi sistem angiotensin seperti ARB baik digunakan pada pasien dengan penyakit DM, karena dapat mencegah terjadinya kerusakan ginjal. Obat pada golongan tersebut memiliki efek nefrontoksik yang terjadi akibat efek vasodilatasi pada arteri efferent di ginjal (Saseen \& Maclaughlin, 2011). Kombinasi tiga obat antihipertensi diberikan pada tekanan darah pasien yang tidak dapat mencapai target dengan dua obat. Contoh kombinasi tiga obat antihipertensi yang disarankan menurut Smith, 
Lennon dan Carlsgaard (2020) yaitu kombinasi obat golongan CCB dengan ARB dan Diuretik.

Pada pasien dengan HHD, $\beta$ Bloker digunakan sebagai terapi lini pertama. Menurut Maraj, Makaryus J, Ashkar, McFarlane dan Markayus A (2013) $\beta$ Bloker telah terbukti meningkatkan kelangsungan hidup, mengurangi risiko infark miokard dan menurunkan insiden kematian jantung mendadak diantara pasien. Selain itu, ARB telah terbukti menjadi pengobatan yang efektif untuk hipertensi pada pasien dengan $\mathrm{CHD}$ dan $\mathrm{HF}$ yang tidak toleran terhadap ACEI. Sehingga, penggunaan kedua obat tersebut secara kombinasi dapat dilakukan (Nurhikma, Wulaisfan \& Musdalipah, 2019).

Kombinasi Diuretik ${ }^{\mathrm{a}}$ dengan ACEI dan CCB digunakan oleh 1 pasien dengan persentase 5,26\%. Mufidah dan Kusumaningrum (2014) menjelaskan bahwa diuretik akan mengurangi volume intrafaskular sehingga mengaktifkan sistem renin angiotensin aldosterone dan dengan adanya ACEI akan terjadi kontraregulasi yang menghambat pengaktifan sistem tersebut, sehingga menghasilkan penurunan tekanan darah yang aditif. Selain itu, ACEI dapat meningkatkan tolerabilitas dan menetralkan efek samping edema perifer pada penggunaan CCB tunggal.

Berdasarkan JNC 8 golongan obat ACEI, ARB, CCB dan Diuretik merupakan terapi utama pada pasien dengan hipertensi. Namun, penggunaan golongan ACEI dan ARB secara bersamaan tidak direkomendasikan. Irawan (2014) menjelaskan bahwa penggunaan kombinasi ACEI dan ARB secara bersamaan dapat menyebabkan efek samping peningkatan serum kreatinin pada ginjal. Hasil penelitian yang berbeda ditunjukkan oleh Misra dan James (2009) yang menyatakan bahwa kombinasi ACEI dan ARB dapat mengurangi proteinuria yang lebih baik daripada pemberian terapi secara tunggal. Sehingga penggunaan kombinasi tersebut dapat dilakukan tetapi harus dalam pengawasan dan diberikan ketika memberikan manfaat yang lebih besar dibandingkan dengan efek samping.

Spesifikasi prespektif diperlukan dalam mengidentifikasi dan mengukur biaya pada analisis farmakoekonomi, karena akan menentukan jenis biaya yang diukur. Sehingga dalam penelitian ini jenis prespektif yang digunakan adalah prespektif rumah sakit. Pada prespektif ini jenis biaya yang diukur yaitu total biaya medik langsung (direct medical cost) atau seluruh biaya yang dikeluarkan oleh pasien untuk mendapatkan perawatan selama di RS PKU Muhammadiyah Yogyakarta. Biaya dikelompokkan berdasarkan pola terapi hipertensi pasien agar dapat diketahui biaya yang dikeluarkan untuk masing-masing terapi.

Biaya depo rawat inap, biaya ruangan dan biaya penunjang adalah komponen biaya yang digunakan pada penelitian ini. Masing-masing komponen biaya merupakan rata-rata per pasien dalam satu jenis pola terapi. Biaya depo rawat inap meliputi biaya obat antihipertensi, biaya obat penunjang dan biaya alat kesehatan yang digunakan pasien. Biaya ruangan meliputi biaya kamar perawatan, biaya konsultasi dan visite dokter, biaya administrasi, serta biaya tindakan medis. Biaya penunjang terdiri dari biaya laboratorium klinik, radiologi, UGD dan penunjang lainnya seperti CT-Scan dan konsultasi gizi.

Hasil penelitian menunjukan bahwa biaya medik langsung pasien hipertensi rawat inap berbeda-beda pada setiap komponennya, hal ini dipengaruhi oleh kondisi pasien, lama hari rawat serta kelas ruang perawatan. Rata-rata total biaya medik langsung pada pasien yang menggunakan pola terapi kombinasi dua antihipertensi ACEI $+\beta$ Bloker, $\mathrm{CCB}+\mathrm{ARB}$, $\mathrm{CCB}+\beta$ Bloker dan ACEI + ARB memiliki nilai rupiah yang lebih tinggi jika dibandingkan dengan pasien yang menggunakan pola terapi kombinasi tiga obat. Hal ini sejalan dengan penelitian yang dilakukan oleh Zulfah, Ikaditya dan Kosasih (2019) bahwa semakin banyak obat 
dalam suatu kombinasi tidak selalu memberikan peningkatan biaya terapi.

Outcome klinik yang dijadikan faktor efektivitas terapi pada penelitian ini yaitu ratarata keberhasilan masing-masing terapi dalam mencapai target tekanan darah berdasarkan JNC 8 pada saat pasien mengakhiri masa perawatannya. Efektivitas terapi disajikan dalam bentuk persentase keberhasilan terapi yang didapatkan dari jumlah pasien yang mencapai target tekanan darah dibagi dengan jumlah total pasien yang menggunakan pola terapi tersebut. Pengelompokkan efektivitas dilakukan berdasarkan jenis kombinasi golongan obat antihipertensi.

Hipertensi merupakan faktor risiko paling umum yang dapat dimodifikasi pada kasus Atrial fibrilasi (AF). Lebih dari seperlima kasus AF baru disebabkan oleh hipertensi dan setiap peningkatan $20 \mathrm{mmHg}$ pada tekanan darah sistolik dikaitkan dengan risiko AF 21\% lebih tinggi (Soliman et al, 2020). Jika pasien memiliki AF persisten kronis, kontrol laju adalah bagian penting dari pengobatan dan obat dapat digunakan untuk mengobati hipertensi yang mendasari AF. Kontrol laju biasanya dicapai dengan menggunakan obat golongan $\beta$ Bloker dan CCB (Cohen \& Townsend, 2017). Sehingga, nilai efektifitas terapi paling baik dicapai oleh pasien yang menggunakan terapi kombinasi obat $\mathrm{CCB}$ dan $\beta$ Bloker dengan nilai efektifitas $100 \%$.

Efektivitas terapi yang rendah pada terapi $\mathrm{CCB}+\mathrm{ARB}+$ Diuretik ditunjukkan pada Tabel (3). Hasil tersebut dapat dipengaruhi oleh penyakit penyerta pasien yaitu DM Tipe 2 dan Dislipidemia, serta lama hari rawat pasien yang hanya satu hari. Kemampuan tubuh dalam menurunkan tekanan darah pada setiap pasien berbeda-beda. Hal ini sejalan dengan penelitian Zulfah, Ikaditya dan Kosasih (2019) yang menyebutkan bahwa dua dari tiga pasien dengan TD tidak terkontrol memiliki masa perawatan yang singkat, sehingga tubuh belum mampu mengontrol TD dengan baik.
Penggunaan terapi Diuretik ${ }^{\mathrm{a}}+\mathrm{ACEI}+\mathrm{CCB}$ pada pasien menunjukkan hasil yang baik dengan rata-rata efektifitas terapi $100 \%$. Angiotensin sistem bloker terbukti efektif dalam perlindungan kardiovaskular dan pencegahan kerusakan organ target. Suatu studi meta analisis yang melibatkan 158.998 pasien hipertensi membuktikan bahwa ACEI dapat menurunkan $10 \%$ penyebab kematian. Selain itu, diuretik direkomendasikan oleh JNC 8 sebagai antihipertensi lini pertama terbukti efektif dalam kombinasi dengan ACEI/ARB dan CCB (Chi et al, 2016).

Hypertension Heart Disease merupakan istilah pada kerusakan jantung secara umum akibat tekanan darah tinggi. HHD sangat berisiko berkembang menjadi Left Ventrikel Hypertrophy. Saseen dan Maclaughlin (2011) merekomendasikan penggunaan ARB dan Diuretik, kemudian ditambahkan $\beta$ Bloker. Efektivitas terapi yang baik ditunjukkan pada pasien yang menggunakan kombinasi empat obat antihipertensi Diuretik ${ }^{\mathrm{a}}+\mathrm{ARB}+\mathrm{CCB}+\beta$ Bloker dengan nilai rata-rata efektivitas $100 \%$.

Berdasarkan Tabel (3) dapat diketahui bahwa pada penggunaan terapi ACEI + ARB dan terapi $\mathrm{ACEI}+\mathrm{CCB}+\beta$ Bloker menunjukkan nilai efektivitas terapi yang rendah. ONTARGET (Ongoing Telmisartan Alone and in Combination with Ramipril Global Endpoint Trial) menjelaskan bahwa terapi kombinasi ACEI dan ARB tidak menurunkan angka kematian dan kejadian kardiovaskular, serta dapat meningkatkan efek samping seperti hiperkalemia dan gagal ginjal akut yang membutuhkan dialisis (Anand dan Tamuran, 2012). Hasil penelitian Tsai et al (2017) menjelaskan bahwa penambahan diuretik merupakan pilihan yang lebih baik daripada obat golongan $\beta$ Bloker untuk pasien hipertensi yang telah menerima ACEI/ARB dan CCB.

Penilaian efektivitas biaya digambarkan sebagai rasio biaya/efektivitas ( $\mathrm{C} / \mathrm{E}$ ratio) yang dilakukan melalui perhitungan ACER dan ICER. Interpretasi hasil dari perhitungan ACER 
menunjukkan jumlah biaya yang dikeluarkan untuk setiap $1 \%$ efektivitas terapi. Berdasarkan Tabel (3) dapat diketahui bahwa terapi Diuretik ${ }^{\mathrm{a}}$ + ARB $+\beta$ Bloker memiliki nilai ACER terendah dengan 15.267, hasil perhitungan tersebut menunjukkan bahwa setiap $1 \%$ efektivitas terapi Diuretik ${ }^{\mathrm{a}}+\mathrm{ARB}+\beta$ Bloker biaya yang dikeluarkan sebesar Rp. 15.267.

Berdasarkan hasil studi obat standar yang ada untuk tatalaksana terapi hipertensi pasien RS PKU Muhammadiyah Yogyakarta disesuaikan dengan panduan yang ada di JNC 8. Sehingga, obat standar yang digunakan pada pasien hipertensi rawat inap adalah kombinasi dua obat antihipertensi CCB + ARB. Perhitungan analisis efektivitas biaya menggunakan ICER dilakukan untuk memberikan beberapa pilihan terapi alternatif yang dapat diterapkan dan untuk menjelaskan besaran biaya tambahan pada setiap perubahan satu unit efektivitas biaya.

Besaran nilai ICER dipengaruhi oleh selisih antara biaya dan efektivitas dua pilihan alternatif terapi. Intrepretasi dari nilai ICER adalah besarnya biaya yang dikeluarkan setiap peningkatan $1 \%$ efektivitas. Pada pasien hipertensi rawat inap di RS PKU Muhammadiyah Yogyakarta tahun 2020 nilai ICER yang diperoleh terapi Diuretik ${ }^{\mathrm{a}}+\mathrm{ARB}+$ $\mathrm{CCB}+\beta$ Bloker dan terapi $\mathrm{CCB}+\mathrm{ARB}$ adalah 31.808. Hasil tersebut menunjukkan antara terapi Diuretik ${ }^{\mathrm{a}}+\mathrm{ARB}+\mathrm{CCB}+\beta$ Bloker dan terapi $\mathrm{CCB}+\mathrm{ARB}$, apabila dipilih terapi kombinasi Diuretik $^{\mathrm{a}}+\mathrm{ARB}+\mathrm{CCB}+\beta$ Bloker, maka pasien harus mengeluarkan tambahan biaya sebesar Rp. 31.808 untuk setiap peningkatan $1 \%$ efektivitas.

Hasil ICER yang diperoleh antara pola terapi kombinasi ACEI + CCB $+\beta$ Bloker + Diuretik $^{b}$ + Agonis $\alpha 2$ Sentral + ACEI memiliki nilai yang terendah dengan Rp. 25.353 jika dibandingkan dengan nilai ACEI $+\beta$ Bloker, $\mathrm{ARB}+\beta$ Bloker. $\mathrm{ACEI}+\mathrm{ARB}, \mathrm{CCB}+\mathrm{ARB}+$ Diuretik, ACEI $+\mathrm{CCB}+\beta$ Bloker, ACEI + $\mathrm{CCB}+\beta$ Bloker + Diuretik $^{\mathrm{b}}$ terhadap terapi standar yang dapat dilihat pada Tabel (5) Hal tersebut terjadi akibat perbedaan jumlah total biaya medik langsung yang relatif lebih rendah antara terapi pembanding dan standar.

Berdasarkan cost effectiveness grid dapat diketahui bahwa terdapat beberapa jenis pola kombinasi obat antihipertensi yang bersifat dominan terhadap terapi standar. Adapun jenis pola terapi tersebut yaitu $\mathrm{CCB}+\beta$ Bloker, Diuretik $^{\mathrm{a}}+\mathrm{ACEI}+\mathrm{CCB}$, Diuretik ${ }^{\mathrm{a}}+\mathrm{ARB}+\beta$ Bloker, $\mathrm{ARB}+\mathrm{CCB}+\beta$ Bloker + Agonis $\alpha 2$ Sentral yang dapat diketahui melalui Tabel (4). Sehingga jenis terapi yang paling cost effective apabila ditinjau melalui parameter ACER dan ICER pada pasien hipertensi rawat inap di RS PKU Muhammadiyah Yogyakarta tahun 2020 adalah Diuretik ${ }^{\mathrm{a}}+\mathrm{ARB}+\beta$ Bloker.

\section{SIMPULAN}

Hasil penelitian menunjukkan bahwa terapi kombinasi tiga obat antihipertensi Diuretik ${ }^{\mathrm{a}}+$ $\mathrm{ARB}+\beta$ Bloker memiliki nilai ACER terendah dengan Rp. 15.257 dan bersifat dominan terhadap terhadap terapi standar, sehingga terapi tersebut merupakan jenis terapi yang paling cost effective.

\section{UCAPAN TERIMA KASIH}

Ucapan terima kasih disampaikan kepada seluruh civitas akademika Universitas Ngudi Waluyo dan RS PKU Muhammadiyah Yogyakarta yang telah membantu dalam pelaksanaan penelitian ini.

\section{DAFTAR PUSTAKA}

American Heart Association. (2021). Hearth Disease and Stroke Statistics 2020 Update a Report from the American Heart Association Inc. Texas: American Heart Association. DOI: 10.1161/CIR.0000000000000757.

Anand, S., \& Tamura, M. K. (2012). Combining Angiotensin Receptor Blockers with ACE Inhibitors in Ederly Patients. Am J Kidney. 59 (1). Hal 11-14. doi:10.1053/j.ajkd.2011.09.002 
Andayani, T. M. (2013). Farmakoekonomi Prinsip dan Metodologi. Yogyakarta: Bursa Ilmu. Hal 73-89.

Aristoteles. (2018). Korelasi Umur dan Jenis Kelamin dengan Penyakit Hipertensi di Emergency Center Unit Rumah Sakit Islam Siti Khadijah Palembang 2017. Indonesia Jurnal Perawat. 3(1). Hal 916.

Aryantiningsih, D. S., \& Silaen, J. B. (2018). Hipertensi Pada Masyarakat di Wilayah Kerja Puskesmas Harapan Raya Pekan Baru. Jurnal IPTEKS Terapan. 12(1). Hal 64-77.

Breu, A. C., \& Axon, R. N. (2018). Acute Treatment of Hypertensive Urgency. Journal of Hospital Medicine. 13 (22). Hal 860-862. DOI 10.12788/jhm.3086.

Chi, C., Tai, M., Bai, B., Yu, S., Karamanou, M., Wang, J., Protogerou, A., Blacher,J., Safar, M. E., Zhang, Y., Xu, Y. (2016). Angiotensin System Blockade Combined with Calcium Channel Blockers is Supirior to Other Combinations in Cardiovascular Protection with Similar Blood Pressure Reduction: A Meta-Analysis in 20,451 Hypertensive Patients. The Journal of Clinical Hypertension. 18 (8). Hal 801808. DOI: $10.1111 /$ jch.12771.

Cohen, D. L., \& Townsend, R. R. (2017). Blood Pressure in Patients with Atrial Fibrillation: Part 2-Treatment. J Clin Hypertens. 19. Hal 212-214. DOI: 10.1111/jch. 12939

Devicaesaria, A. (2014). Hipertensi Krisis. Medicinus. 27 (3). Hal 9-17.

Dinkes DI Yogyakarta. (2020). Profil Kesehatan Daerah Istimewa Yogyakarta Tahun 2019. Daerah Istimewa Yogyakarta: Dinas Kesehatan.

Dorian, P., \& Angaran, P. (2014). $\beta$-Blockers and Atrial Fibrillation: Hypertension and Other Medical Conditions Influencing Their Use. Canadian Journal of
Cardiology. 30. Hal S38-S41. http://dx.doi.org/10.1016/j.cjca.2013.09. 029

Irawan, A. (2014). Peningkatan Serum Kreatinin Akibat Penggunaan ACEI atau ARB Pada Pasien Hipertensi. Jurnal Farmasi Klinik Indonesia. 3 (3). 83-87.

James, P.A., Oapril, S., Carter, B.L., Cushman, W.C., Himmelfarb, C.D., Handler, J., Lackland, DT., LeFevre, M.L., MacKenzie, T.D., Olugbenga, Ogedegbe., Smith, SC.., Svetkey, L.P., Taler, S.J., Townsend, R.R., Wright, J.T., Narva, A.S., \& Ortiz, Eduardo. (2014). Evidence-Based Guideline for the Management of High Blood Pressure in Adults Report from the Panel Members Appointed to the Eight Joint National Commite (JNC 8), JAMA. https://jamanetwork.com/

Kemenkes R.I. (2019). Infodatin Hipertensi si Pembunuh Senyap. Jakarta Selatan:

Maraj, I., Markayus, J. N., Ashkar, A., McFarlane, S. I., \& Markayus, A. N. (2013). Hypertension Management in the High Cardiovascular Risk Population. International Journal of Hypertension. Hal 1-6. http://dx.doi.org/10.1155/2013/382802.

Misra, S., \& Stevermer, J. J. (2009). ACE Inhibitors and ARBs: One or the Other Not Both for High Risk Patient. The Journal of Family Practice. 54 (1). Hal 24-27.

Muhadi. (2016). JNC 8: Evidence-based Guideline Penanganan Pasien Hipertensi Dewasa. CKD-236, 43 (1), 54-60.

Nafrialdi. (2007). Antihipertensi. Dalam Gunawan, S. G., Setiabudi, R., Nafrialdi., Elysabeth (Ed), Farmakologi dan Terapi Edisi 5 (hal 341-360). Jakarta: ECG.

Nurhikma, E., Wulaisfan, R., \& Musdalipah. (2019). Cost Effectiveness Kombinasi Antihipertensi Candesartan-Bisoprolol dan Candesartan-Amlodipin Pada Pasien 
Rawat Jalan Penderita Hipertensi. Jurnal Profesi Medika: Jurnal Kedokteran dan Kesehatan. 13 (2). Hal 54-61. DOI: http://dx.doi.org/10.33533/jpm.v13i2.12 84

Putri, A. S. (2018). Analisis Biaya Terapi Pasien Diabetes Melitus Tipe 2 di Instalasi Rawat Inap RSUD $d r$. Soekardjo Tahun 2017 (Karya Tulis Ilmiah). Poltekkes Kemenkes Tasikmalaya.

Putri, L. S. A., Satriyasa, B. K., \& Jawi, I. M. (2019). Gambaran Pola Penggunaan Obat Antihipertensi Pada Pasien Hipertensi di Instalasi Rawat Inap RSUP Sanglah Denpasar Tahun 2016. Jurnal Medika Udayana. 8 (6).

Rahayu. A., Afdhal, A.F., Hasan, D., Suwarna, F., \& Meilia, O. (2020). Analisis Efektivitas Biaya Terapi Antihipertensi Kombinasi Tetap di Satu Rumah Sakit Jakarta Selatan. Pharmacoscrip, 3 (1), 38-53.

Richards, T. R., \& Tobe, S. W. (2014). Combining Other Antihypertensive Drugs with $\beta$-Blockers in Hypertension: A Focus on Safety and Tolerability. Canadian Journal of Cardiology. 30. Hal S42-S46.

Saseen, J. J., \& Maclaughlin, E. J. (2011). Hypertension. dalam Dipiro, J. T., Talbert, R. L., Yee, G. C., Matzke, G. R., Wells, B. G., Posey, L.M (Ed.). Pharmacotherapy A Pathophysiologic Approach $8^{\text {th }}$ Edition (hal 101-132). New York: Mc-Graw Hill.

Smith, D. K., Lennon, R. P., \& Carlsgaard, P. B. (2020). Managing Hypertension Combination Therapy. American Family Physician. Hal 1-9.

Soliman, E. Z., Rahman, F., Zhang, Z., Rodriguez, C. J., Chang, T. I., Bates, J.
T., Ghazi, L., Blackshear, J. L., Chonchol, M., Fine, L. J., Ambrosius, W. T., \& Lewis, C. E. (2020). Effect of Intensive Blood Pressure Lowering on the Risk of Atrial Fibrillation. Hypertension. Hal 1491-1496. DOI: 10.1161/HYPERTENSIONAHA.120.14 766

Sugiono., \& Puspandhani, M. E. (2020). Metode Penelitian Kesehatan. Bandung: Alfabeta. Hal 157-161.

Tabrizi, J. S., Bazargani, H. S., Farahbakhsh, M., Nikniaz, L., Nikniaz, Z. (2016). Pravalence and Associated Factors of Prehypertension and Hypertension in Iranian Population: The Lifestyle Promotion Project (LPP). PLOS ONE, $11 \quad$ (10), 1-15. DOI:10.1371/journal.pone.0165264.

Udayani, N. N. W., Riastini, N. W., \& Putra, I. M. A. S. (2017). Perbedaan Efektivitas Penggunaan Obat Amlodipin Tunggal dengan Kombinasi Amlodipin dan Lisinopril Pada Pasien Hipertensi Rawat Inat di RS ' $\mathrm{X}$ ' Tabanan Tahun 2017. Jurnal Ilmiah Medicamento, 4 (2), 128133.

Wahyuningtiyas, D. A. (2015). Analisis Efektivitas Biaya Terapi Antihipertensi Pada Pasien Hipertensi Rawat Inap di Rumah Sakit Umum Daerah Dr. Moewardi Tahun 2014 (Skripsi). Universitas Muhammadiyah Surakarta.

WHO. (2014). Global Status Report on NonCommunicable Disease. Switzerland: World Health Organization.

Zulfah, M., Ikaditya, L., \& Kosasih, E. D. (2019). Analisis Efektivitas Biaya Kombinasi Obat Antihipertensi Pada Pasien Rawat Inap di RSUD Dr. Soekardjo Tasikmalaya. Jurnal of Pharmacopolium, 3 (1), 53-62. 